\title{
AS FORMAS DA PRAXE FORENSE (*)
}

\section{TITULO I}

\section{A jurisprudencia dos arestos}

\section{CAPITULO I}

Summario.-Etymologia da palavra--aresto.- Sentido da palavra-facanhas, empregada na Ord. L. II tit. XXXV § 26.-Definição.-Differença entre os arestos e os Assentrs.-Divisão dos arestos em França.-Divisão dos arestos em Portugal. - Divisão dos arestos no Brazil no tempo do Imperio.-As tenções e as conferencias.-Divisão dos arestos no systema republicano federal.-Superior categoria dos arestos do $\mathrm{Su}-$ premo Tribunal Federal sobre os arestos dos tribunaes dos Estados e instabilidade da ficção da soberania dos Estados na organisação actual.

1. A etymologia da palavra-aresto-occasionou divergencia entre os lexicographos: uns a derivam do francez-arrêt, arrêter, que significa-parar, permane-

(*) A praxe forense é um deposito de dados da experiencia: a palavra praxe corresponde ao aoristo grego-epraxa, significando aquillo que tem sido sempre praticado; a palavra pratica refere-se ao proprio exercicio da actividade, isto é, não só ao que já tem sido praticado, como ao que presentemente praticamos, como ao que ainda vamos praticar. A praxe é o mais poderoso auxilio para a pratica, porque firma as regras latentes, revelando, nas minudencias dos casos julgados, todas as consequencias que a experiencia tem tirado das regras expressas no texto da lei. E' por isso que, na phrase de JHERING, a praxe «é o precipitado da sã razão humana em materia de Direito», isto é, o complexo de experiencias que "passaram milhares de vezes pelo cadinbo do pensamento e da vida pratica». Ora, as formas organicas ou manifestações dessas experiencias são os arestos, os estylos, os usos e observancias, os pareceres concordes dos jurisconsultos e praticos, a opinião commum dos praxistas e os formularios. 
cer, ficar, fixar, terminar; outros do latim-ad (a ou para) e restare (ficar, permanecer); outros, do grego areston, que significa decreto, resolução, decisão. Os partidarios da derivação franceza, dominados pela leitura do jurisconsulto Dupin, que escreveu um brilhante opusculo sobre a jurisprudencia dos arestos, affirmam que esta palavra appareceu no fôro francez antes de ser empregada na praxe de outros paizes, isto é, appareceu pela primeira vez em um julgamento em I 278 contra o rei, em favor do duque de Alençon, julgamento que principiava pelas palavras - Dictum fuit per arrestum; depois, a expressão encontra-se nas Ordenanças do Louvre, tom. I, pag. 320 , isto é, no art. 6. da Ordenança de Philippe, o Bello, do anno de I 291; sobretudo, a expressão franceza-arrêt-foi adoptada depois que Francisco I, por sua Ordenança de I 539, art. I I I, determinou que - «d'oresnavant tous arrêts... et autres actes quelconques seraient prononcés, enregistrés et delivrés aux parties en langage maternel français et non autrement.» Os partidarios da derivação latina fundam-se em que, antes dessa Ordenança de Francisco I, os julgamentos eram proferidos em latim, que era a lingua do direito em todos os povos civilisados da Europa, tanto assim que, mesmo nos actos extrajudiciaes, taes como as escripturas de contractos, sómente no seculo XIII se introduziu o uso da respectiva lingua nacional. Os partidarios da derivação gregá fundam-se, não só na origem commum com a latina, como por ser mais semelhante na pronuncia á palavra portugueza e mais explicativa da significação da cousa; accrescentanı que Cabedo, Phebo, Mendes, França e outros reinicolas usavam da expressão aresto, mantendo, no som do r, não a voz vibrante do arrestum dos francezes, mas a voz liquida do areston, dos gregos. Não vemos realmente razão para buscar no francez a origem da palavra-aresto, 
que é greco-latina $\epsilon$ pertence a todas as linguas romanicas. Os proprios jurisconsultos francezes referem-se a uma obra de Craterus, favorito de Alexandre Magno, obra que se perdeu, a qual continha as decisões do Areopago e do Conselho dos Amphyctiões, sob a denominação grega-areston.

2. A palavra-aresto-encontra-se nos trabalhos dos decisionistas e praxistas reinicolas, não porém no texto das Ordenações e leis extravagantes. A Ord. L, II tit. XXXV $\S 26 \mathrm{diz}$ : «..... sem embargo de quaesquer direitos canonicos, civis, costumes, façanhas e estylos». Em uma dissertação sobre o verdadeiro sentido desta palavra-façanhas, empregada na cit. Ordenação, estudo de José Anastacio de Figueiredo, inserto no tomo I das Memorias da Academia Real de Sciencias de Lisboa, ahi está notado que DuARTe Nunes Do LĨ̃o, na Parte Primeira da Chronica-dos Reis de Portugal, affirma que façanha «é um juizo sobre algum feito notavel e duvidoso, que por autoridade de quem o fez e dos que o approvaram e louvaram, ficou delle um direito introduzido para se imitar e seguir como lei, quando outra vez acontecesse». CABEDo, aliás não contestando a definição de Duarte Nunes, amplia o sentido da palavra, affirmando que façanha, "é o mesmo que opinião altercada». Outra definição dá D. Rodrigc da Cunha, na Historia Ecclesiastica de Lisboa, a quil definição, em fundo, é a mesma de Duarte Nunes; pois, façanha, diz elle, «é um tal e tão generoso feito que, assim pela estranheza e valor com que foi obrado, como pela autoridade da pessoa que obrou e daquelles que o louvaram e celebraram, mereceu e alcançou um prudencial juizo de ser tido e havido por lei onde concorressem iguaes ou semelhantes circumstancias». $O$ referido Jcsé Anasiacio de Figueiredo corrige a 
definição de Duarte Nunes, por isso que muito antes dos exemplos por este referidos, já a expressão-façanta «se tomava por quaesquer exemplos de juizos ou sentenças, que se dessem principalmente em casos em que as Leis do Paiz não dessem providencia e que fossem duvidosos por serem omissos; e, como taes juizos ou sentenças podiam ser dadas pelos Reis, ou pelos Magistrados, ou por Arbitros, por isso nas Leis das Partidas e outras se tira toda a autoridade, para serem allegadas e seguidas, a quaesquer sentenças ou determinaç̃oses em outros casos dadas, desde que estas sentenças ou determinações não fossem das proferidas pelos Reis, porque sómente estas tinham força de Lei em casos semelhantes; além disso, não era necessario que a sentença ou determinação fosse sobre feito notavel, bastando que o caso occasionasse $d u$ vida na applicaşâa da Lei ou fosse nella omisso.» Posteriormente, isto é, já no seculo XVI, a expressão $f a$ çanha cahiu em desuso, para dar lugar á expressão -caso julgado, que figurava no titulo das Consultas de Valasco e das Decisões de Gama. Os nomescasos julgados e arestos, diz a supracitada Memoria, «foram os que melhor succederam ao antigo façanhas.» E, por fim, Cabedo, Phebo, Mendes e França já usam da expressão-arestos, que é adoptada na praxe hodierna.

3. Chamam-se arestos as decisð̃es judiciaes, não susceptiveis de reforma, proferidas, em forma de julgamento definitivo, pelos tribunaes superiores. $\mathrm{O}$ citado Dupin observa que, em França, não raro aconteceu que os tribunaes subalternos e mesmo os juizes singulares tivessem a pretenção de dar o nome de arestos ás suas decisões: foi mesmo necessario que uma lei, o Senatus consulto do 28 Floreal do anno XII, art. I 34, viesse profligar tal ambição. Por outro lado, 


\section{$-11-$}

não faltaram autores que, reproduzindo ou referindo-se a simples sentenças ou decretos, as denominassem arestos. Ainda as decisões dos tribunaes soberanos, quando se limitam a confirmar as sentenças dos tribunaes subalternos ou dos juizes singulares," não podem constituir arestos; pois, só podem ser como taes consideradas as decisões proferidas pelos proprios tribunaes soberanos, como julgamento formal, posto que em gráo de recurso, contendo os nomes e qualidades das partes litigantes, as questões de facto e de direito estabelecidas com precisão, o resultado dos factos reconhecidos pela prova, as razões de decidir $\mathrm{e}$ o dispositivo. Não raro acontece que os juizes dos tribunaes soberanos, para pouparem-se ao trabalho de redigir fundamentos, confirmam as sentenças dos juizes inferiores com a formula-«confirmam por seus fundamentos que adoptam por serem conformes ao Direito e á prova dos autos.» A proposito disso, os jurisconsultos assignalam a conveniencia dos Tribunaes motivarem as decisões, ainda mesmo as que confirmam as dos juizes inferiores: razões mais solidas, razões identicas expostas com maior clareza, razões diversas ou differentes produzindo a mesma consequencia, dariam maior realce e autoridade ao julgamento. A verdade é que, na praxe, ninguem dá a uma sentença simplesmente confirmada o mesmo valor que dá ao julgamento fundamentado de um tribunal soberano.

4. Não confundamos os arestos com os Assentos. Os Assentos são actos do poder judiciario, mas não são julgamentos de casos particulares, não resolvem litigios hic et nunc, isto é, são determinações sobre a intelligencia das leis, quando na execução dellas occorrerem duvidas manifestadas por julgamentos divergentes: os arestos são casos julgados entre certas e determinadas partes litigantes. Os Assentos associam 
- poder judiciario ao poder legislativo, ao passo que os arestos mantêm o poder judiciario na esphera de suas attribuições: os Assentos são leis, ao passo que os arestos são simples exemplos que podem ser seguidos ou não em casos semelhantes e que não obrigam sinão ás proprias partes que intervieram no feito. Toda a força dos Assentos da Casa de Supplicação de Lisboa decorre do disposto na Ord. L. I, tit. V $\S 5$, a qual foi positivamente declarada pelos Decrs. -de 4 de Fevereiro de 1684 e de 20 de Junho de I 703 e posteriormente confirmada pela Lei de i 8 de Agosto de I 769, mórmente por esta ultima, $\S \S$ I a 6 , onde bem determinado fica que nos Assentos «se não julga o direito das partes no particular de cada uma dellas, mas $\operatorname{sim}$ a intelligencia geral e perpetua da Lei em commum beneficio.» A Lei n. 2684 de 23 de Outubro de 1875 veiu cortar qualquer duvida que houvesse sobre a força dos Assentos da Casa de Supplicação de Lisboa, depois da creação da do Rio de Janeiro até a epocha da Independencia, pois que taes Assentos, á excepção dos que estivessem derogados pela legislação posterior, ficaram expressamente com força de lei em todo o Imperio, sem prejuizo dos casos julgados contra ou conforme os ditos Assentos; outrosim, o Supremo Tribunal de Justiça ficou com a attribuição de tomar Assentos para intelligencia das leis civis, commerciaes e criminaes, quando na execução dellas occorressem duvidas manifestadas por julgamentos divergentes havidos no mesmo Tribunal, Relações e Juizos de primeira instancia. O Decr. n. 6142 de io de Março de 1876, regulando essa attribuição, determinou no art. $20^{\circ} \S$ unico, ao envez do disposto na Ord. L. I tit. $\mathrm{V} \S 55^{\circ}$, que para ter lugar a providencia dos Assentos, era indispensavel que os julgamentos causadores da divergencia já tivessem sido proferidos em processos findos e que a di. 
vergencia tivesse por objecto o direito em these ou a disposição da lêi e não a variedade da applicação proveniente da variedade dos factos; por outro lado, determinou esse Decreto, no art. $3 .^{\circ}$, que os Assentos tomados não prejudicariam os casos julgados contra ou conforme a doutrina que estabelecessem. Por tudo isto, bem se comprehende a differença que ha entre os Assentos e os arestos: basta dizer que estes são casos particulares julgados e aquelles são disposições genevicas. Parece que, segundo a indole do actual regimen republicano, já não é licito associar o poder judiciario ao poder legislativo e que, portanto, essa attribuição de tomar Assentos não póde ser conferida aos tribunaes, quer federaes quer estadoaes.

5. Outr'ora, no regimen absoluto, não havendo divisão de poderes, bem se sabe quanto contribuiram os juizes para a elaboração da lei; aliás, é força reconhecer que o direito existiu antes da lei positiva que o reconheceu e firmou, de sorte que o juiz precedeu ao legislador: d'ahi se deprehende que os exemplos, os casos julgados, foram originariamente as regras para casos identicos ou analogos. Não é de estranhar, pois, a antiga divisão franceza, a que se refere o citado Dupin, em arestos de ordem publica e arestos de ordem privada, subdivididos os primeiros em arestos de registro e arestos de regulamento. Os arestos de registro eram importantes pela faculdade que tinham as côrtes ou parlamentos de não registrar edictos, declarações, cartas, etc., fazendo préviamente ponderações ao Rei em opposição ás suas ordens, para maior bem e vantagem de seu reino. «Jámais temeremos soffrer qualquer contrariedade, quando, por oppostas á justiça, fôr suspensa a execução das nossas ordens», dizia - Imperador Theodorico a Cassiodoro. Os arestos de regulamento eram os proferidos sobre os pontos de 
direito costumeiro, alta policia, disciplina, processo, fiscalisação, etc., e tinham força de lei emquanto o Rei não mandasse o contrario.

6. Em Portugal não se tornou tão efficaz a influencia dos tribunaes em assumptos de ordem politica e administrativa, de sorte que jámais cogitaremos de taes arestos de ordem publica; para nós, os arestos são sómente os casos julgados sobre interesses e direitos de particulares. Primitivamente, distinguiam-se pela qualidade dos juizos, isto é, segundo as sentenças eram proferidas pelos Reis, pelos Magistrados ou por Arbitros, sendo que só os primeiros tinham força de lei. Depois da organisação judiciaria das Ordenações, os arestos distinguiam-se pelos tribunaes que os proferiam. Quanto ao Tribunal ou Mesa do Desembargo do Paço, por ter attribuições mais de jurisdicção graciosa do que contenciosa, ninguem lembrou-se de chamar-arestos ás suas decisões, de sorte que, entre os decisionistas, os arestos foram classificados em arestos de Casa de Supplicação de Lisbôa, arestos da Casa do Porto e arestos das Relacões, sendo que os primeiros tinham maior autoridade que os segundos e estes do que os ultimos. A's decisões da Casa de Supplicação de Lisbôa, - Conde DA ERIceira, no Portugal restaurado, chama arestos do Parlamento, «quando tomadas diante d'El Rey e mandando-o elle guardar em casos semelhantes». Não faltou quem quizesse entender que essa expressão arestos do Parlamento estendia-se ás decisões tomadas sobre glosas, quer do Chanceller-mór, quer do Chanceller da Casa de Supplicação, quer do Chanceller da Casa do Porto, glosas essas que esses chancelleres eram obrigados a pôr nas provisões, cartas ou sentenças, quando vissem que eram expressamente contra as Ordenações ou Direito, e cuja execução deveria ser suspensa até que resolvida fosse a glosa, nos termos da Ord. L. I, 
tit. II, tit. IV e tit. XXXVI; mas, a verdade é que, entre os praxistas reinicolas, nenhum lembrou-se de confundir taes decisões com os arestos do Parlamento, a que se refere o citado CoNDE DA ERICEIRA, nem de usar de tal expressão e muito menos de considerar as decisões de ordem publica ou puramente administrativas como constituindo arestos. $\mathrm{Na}$ jurisprudencia portugueza, portanto, aquella classificação de Dupis nem mesmo tem valor historico, porque sempre se consideraram arestos apenas os casos julgados definitivamente pelos tribunaes judiciarios soberanos sobre direitos e interesses de particulares.

7. Na organisação judiciaria dos tempos coloniaes, sem fallarmos no Tribunal ou Mesa do Desembargo do Paço, que, como dissemos, era mais de jurisdição graciosa do que contenciosa, e cujas attribuições foram fixadas pela Ord. L. I, tit. III e pela Lei de 27 de Julho de 1582, havia a Casa de Supplicação de Lisbôa, a Casa do Porto, depois mais as Relações da India ou de Gôa, a do Brazil, com séde na Bahia, cujo regimento foi dado por Leis de 7 de Março de I609 e de I 2 de Setembro de $\mathbf{6 5 2}$, e posteriormente as Relações do Rio de Janeiro (Alvará de I 3 de Outubro de I75I), de S. Luiz do Maranhão (Alvará de 13 de Maio de I8 1 2), de Pernambuco (Alvará de 6 de Fevereiro de i 82 I). Note-se que, por Alvará de ro de Maio de ı 808, com a vinda da Familia Real para o Brazil, foi creada uma Casa de Supplicação no Rio de Janeiro, á qual ficaram subordinadas as causas que se julgavam na antiga Relação, por isso que os desembargadores desta passaram a servir no novo Tribunal; e, bem assim, por Alvará de 22 de Abril desse mesmo anno, foi creada no Brazil outra Mesa do Desembargo do Paço. Proclamada a independencia do Brazil e promulgada a Constituição 
Politica do Imperio, na qual, art. I 5 I, ficou estabelecida a garantia da divisão dos poderes e a consequente independencia do poder judicial, foi por Lei de 18 de Setembro de 1828 creado o Supremo Tribunal de Justiça, como tribunal de revista, segundo a promessa dos arts. IO3 e IO4 da mesma Constituição, sem prejuizo das Relações que continuaram a existir, ficando assim extincta a Casa de Supplicação; e, nesse mesmo anno de I 828, por Lei de 22 desse mesmo mez de Setembro, ficaram extinctas as Mesas do Desembargo do Paço e da Consciencia e Ordens, determinando-se que os negocios da competencia desses tribunaes extincctos, e que ficavam subsistindo, fossem expedidos por outras autoridades então designadas. O, Decr. de 20 de Dezembro de i 830 deu a forma do processo das revistas; o Decr. de 3 de Janeiro de 1833 deu regulamento ás Relações do Imperio; o Decr. n. 9 de 17 de Fevereiro de 1838 marcou os casos em que as Relações divisoras tinham de decidir da nullidade ou injustiça e do merecimento das causas; o Decr. de 22 de Junho de 1834 modificou algumas disposições do regulamento das Relações. O Decr. n. 5618 de 2 de Maio de 1874 , dando novo regulamento ás Relações, dividiu o territorio do Imperio em onze districtos de Relações, determinando-lhes as sédes, a composição dos tribunaes, a competencia, attribuições do presidente, procurador da Corôa, secretario e mais empregados, ordem do serviço e processo, sendo que já o Decr. n. 2842 de 6 de Agosto de I 873 tinha creado mais sete Relações no Imperio e já o Decr. de 12 de Novembro de 1873 tinha dado novo regulamento para interposição de aggravos e appellações.

8. Antes de nos referirmos á organisação judiciaria da Republica, isto é, á que veio depois dos acontecimentos de 15 de Novembro de 1889 , preci- 
samos comparar o processo nos tribunaes antigos e nos tribunaes modernos. Os desembargadores da Casa de Supplicação despachavam por tenções as appellações civeis, os aggravos ordinarios e os instrumentos de aggravo, e despachavam por conferencia, isto é, por votos em Meza, as appellações crimes. Nos feitos por. tenções, eram estas escriptas ordinariamente na lingua latina, em um papel apartado, que o respectivo desembargador não ajuntava ao feito, datava e assignava e o entregava com o feito ao desembargador seguinte, declarando a data da entrega; e depois que o segundo desembargador tinha visto o feito, si concordava com a tenção do primeiro, escrevia a sua e a levava á Relação com o feito, que, si fosse de qualidade de bastarem dous conformes, teria logo sentença, e si não, iriam passando o feito com as tenções a terceiro e a outros na mesma ordem, sendo que, antes de publicada a sentença, as tenções eram por elles guardadas em segredo; finalmente, faziam coser as tenções e, depois de cosidas, punham a sentença, datavam e assignavam, e isto na mesma audiencia da publicação. As Ord. L. I, e tit. II. $\S \S 6,7$ e 8 , e IV $\S \S$ e I 7 , assim como os Assentos de 29 de Abril de I659, i 8 de Julho de I69ı e I 7 de Março de I 7r8, trazem não só o processo como as regras para regular o vencimento e a reducção dos votos, quer nas appellações crimes em que julgavam por conferencia, quer nos feitos em que julgavam por tenções. Este mesmo systema de despachar os feitos civeis por tenções - foi mantido para a Relação do Brazil como para as Relações posteriormente creadas, isto é, para as Relações do Rio de Janeiro, S. Luiz do Maranlão e de Pernambuco. Mas, as sentenças, depois do accordo, isto é, os Accordams, tanto da Casa de Supplicação e da Casa do Porto, como das Relações, eram lavirados em portuguez, datados e assignados. A Lei de 23 de Maio de i 82 I 
abolio o «estylo das tenções em latim, praticado nas Relaçбes do Reino, devendo aquellas ser escriptas em lingua portugueza»; e a Portaria de 3 I de Março de 1824 , confirmando o preceito do Ord. Liv. III, tit. LXVI $\S 77^{\circ}$, determinou que todas as sentenças fossem lançadas, «declarando os juizes, circumstanciada e especificadamente, os fundamentos das mesmas». A Lei de 18 de Setembro de 1828, que creou o Supremo Tribunal de Justiça, e a de 3 de Janeiro de 1833 , dando regulamento ás Relações do Imperio, alteraram o expediente dos julgamentos, determinando que cada Ministro ou Desembargador porá no processo a simples declaração de o ter visto e o passará ao que immediatamente se lhe seguir; e, depois que o ultimo tiver visto o processo, o apresentará no dia que o presidente designar, e então, a portas abertas, será debatida a questão, lançando-se nos autos o resultado com os fundamentos e podendo os divergentes assignar com a nota de vencidos e dar as razões de sua divergencia. Ficou, assim, extincto o systema das tenç̃os em apartado, passando os feitos, quer civeis quer crimes, a ser despachados em conferencia e com discussão publica.

9. A Republica encontrou, portanto, duas ordens de tribunaes soberanos, o Supremo Tribunal de Justiça e as Relações, e assim duas classes de arestos, sendo que os primeiros tinham mais autoridade do que os ultimos, principalmente quando as Relações revisoras acceitavam os fundamentos da revista; ou antes, havia tres classes de arestos, conforme eram elles ou Accordams das Relações, ou Sentenças de revista, ou Accordams revisores, por isso que as Sentenças de revista limitavam-se a discutir e declarar a injustiça notoria ou nullidade manifesta e designavam uma das Relaçoes para revisão e novo julgamento. Constituido 
o organismo do systema federativo pela Const. de 24 de Fevereiro de I89I, estabeleceu-se a dualidade do poder judiciario, isto é, o poder judiciario federal ou da União e o poder judiciario dos Estados, determinando-se desde logo as raias da jurisdicção federal, cuja organisação aliás fôra dada pelo Decr. n. 848 de I I de Outubro de 1890 , exercendo-se a justiça federal por um Supremo Tribunal Federal, com séde no Districto Federal e por juizes inferiores singulares, denominados Juizes de Secção, com séde no Districto Federal e em cada um dos Estados. Por sua vez, os Estados ficaram com o direito de organizar o seu poder judiciario; e as decisões dos seus tribunaes e juizes porão termo aos processos e ás questões, salvo quanto a habeas-corpus e a espolio do estrangeiro quando a especie não estiver prevista em convenção ou tratado. As justiças dos Estados não podem intervir em questões submettidas aos tribunaes federaes, nem annullar, alterar ou suspender as suas sentenças ou ordens; e, reciprocamente, a justiça federal não póde intervir em questões submettidas aos tribunaes dos Estados, nem annullar, alterar ou suspender as decisões ou ordens destes, exceptuados os casos expressamente declarados na Constituição. Até agora os Estados têm organisado as suas justiças com um só tribunal supremo e juizes singulares inferiores, limitando-se sempre a duas instancias e conservando, em seus traços geraes, o processo anterior.

10. A classificação e influencia dos arestos, no systema actual, decorre do art. 59, n. I I I, $\S 2 .^{\circ}$ da Constituição Federal, o qual assim dispõe: "Nos casos em que houver de applicar leis dos Estados, a justiça federal consultará a jurisprudencia dos tribunaes locaes e, vice-versa, as justiças dos Estados consultarão a jurisprudencia dos tribunaes federaes, quando 
houverem de interpretar leis da União». D'ahi a divisão dos arestos em arestos dos tribunaes federaes $\mathrm{e}$ arestos dos tribunaes locaes. Mas, quaes são os casos em que os tribunaes federaes têm de applicar as leis dos Estados?... E' certo que, segundo a exposição de motivos que acompanhou o Decreto n. 848 de II de Outubro de I 890 , "perante a justiça federal derimem-se não só as contendas que resultam do direito civil, como aquellas que possam avultar na elevada esphera do direito publico»: haverá algum caso de direito publico, regulado por lei do Estado e que possa ser decidido pelos tribunaes federaes, tendo em vista jurisprudencia dos mesmos Estados?... Parecenos que esse art. 59, n. III, $\S 2 .^{\circ}$ da Constituição, o qual é uma reproducção do art. 36I do citado Decr., contém um paradoxo; pois, determinadas as jurisdicções e competencias como o foram, os tribunaes federaes jámais terão occasião de applicar leis dos Estados, aø passo que os tribunaes dos Estados terão sempre de interpretar e applicar leis da União. Basta considerar que só a união legisla sobre o direito civil, commercial e criminal da Republica e, portanto, sobre as relações de direito sujeitas á apreciação quer da justiça federal quer das justiças locaes. Entretanto, si esse art. 59, n. III, $\S 2 .^{\circ}$ da Const. e 36 I do cit. Decr. contêm esse paradoxo sobre a influencia reciproca dos arestos, nem por isso é inexacta a classificação que autorisa. Aliás, impõe-se a superioridade dos arestos dos tribunaes federaes sobre os arestos dos tribunaes locaes, attendendo-se que, nos termos do cit. art. 59 da Constituição, ao Supremo Tribunal Federal compete, além de processar e julgar originariamente os casos mais importantes da vida social, além de julgar em gráo de recurso as questões resolvidas pelos juizes de secção (cuja competencia está determinada no art. 60), além da revisão dos processos findos em 
materia crime,--conhecer ém gráo de recurso e ultima instancia das sentenças das justiças dos Estados: «a) quando se questionar sobre a validade ou applicação de tratados e leis federaes e a decisão do tribunal do Estado fôr contra ella; b) quando se contestar a validade de leis ou de actos dos governos dos Estados em face da Constituição ou das leis federaes, e a decisão do tribunal do Estado considerar validos esses actos ou essas leis impugnadas». Em geral, não ha relação de direito, das sujeitas aos tribunaes locaes, em que a contestação não verse sobre a applicação ou de leis civis, ou de leis commerciaes ou de leis criminaes da Republica, as quaes, nos termos do art. 34 da Const., são sempre leis federaes; por conseguinte, o recurso facultado pelo art. 59 cit. entra na ordem dos recursos ordinarios e constitue o Supremo Tribunal Federal em uma instancia superior aos tribunaes locaes. Não desconhecemos que alguns fundadores do actual systema politico pretendem que o nosso organismo judiciario repousa sobre a existencia de duas soberanias: mas, a verdade é que a Constituição de 24 de Fevereiro de I89I, principalmente no art. 59, n. III, $\S$ I. $^{\circ}$ lettra $a$, usando das palavras - «ou applicação», incumbiu-se de mostrar que essa dualidade de soberania não passa de uma instabilissima ficção. "Todos os poderes publicos exercem, segundo a natureza especial de suas funcções, certas attribuições soberanas, diz Schutzenberger, e assim, o poder judiciario, quando decide em ultima instancia, julga soberanamente»; neste sentido, podem ser considerados soberanos até os juizes de direito, quando decidem as appellações nas acções summarissimas, e mesmo os juizes de paz, quando das suas sentenças não é interposto recurso algum. Mas, considerada em these, a possibilidade do recurso, isto é, a cousa soberanamente julgada no sentido definido por Prmenta 
Bueno (Apontamentos do Proc. Civil, n. 185), a verdade é que, tratando-se sempre, nos tribunaes dos Estados, de applicar leis federaes, o vencido sempre poderá fundar o seu insuccesso na affirmação de que a decisão respectiva é contraria á applicação dessas leis e, em consequencia, sempre poderá recorrer para - Supremo Tribunal Federal. Em summa, actualmente no Brazil só decide sempre em ultima instancia um unico tribunal e esse é o Supremo Tribunal Federal. Os arestos do Supremo Tribunal Federal têm, por conseguinte, maior autoridade do que os arestos dos tribunaes de justica estadoal. 


\title{
CAPITULO II
}

\author{
Summario.-Fundamento da autoridade dos arestos. \\ - Limites desta autoridade. - Os arestos de \\ equidade, em França.-Os casos de equitiy e \\ common laze, na Inglaterra e nos Estados Uni- \\ dos da America do Norte.-Absurda disposição \\ do art. 387 do Decr. n. 848 de II de Outu- \\ bro de 1890 .
}

11. A lei positiva, em suas applicações, rege minudencias não previstas e exige do magistrado a prudencia necessaria para tirar as legitimas consequencias do texto, consequencias que são regras latentes nesses mesmos textos. $\mathrm{E}$ isto foi sempre consagrado pelos legisladores que, si por um lado determinavam - non exemplis sed legibus judicandum est (Cod., L. I 3 de Sent.), por outro diziam-in ambiguitatibus que ex lege proficiscuntur, rerum perpetuo similiter judicatarum auctoritatem, vim legis obtinere debere (Dig., L. 38, de Legib.) Nem é possivel que, nas variadas, multiplas e minuciosas circumstancias da vida, o legislador tenha a pretenção de tudo prever e prover. Por isso, dizia o grande Portalis, ao lado do sanctuario das leis e sob a vigilancia do legislador, vemos formar-se um deposito de maximas, de 
decisōes e de doutrinas, o qual, se apurando dia por dia pela pratica e pelo choque dos debates judiciarios, augmentando sem cessar os conhecimentos adquiridos, sempre foi considerado como o verdadeiro supplemento da legislação. Fus honorarium viva vox est juris civilis (Dig., de just. et-jure, L. 8). E' esta a origem e $\circ$ fundamento da autoridade dos arestos. Accresce que, como diz Savigny, «as decisões dos tribunaes differem dos antigos julgamentos populares pela instrucção scientifica dos magistrados e pelas tradições que se estabelecem no seio dos collegios permanentes. . Ahi se reproduz a identidade do direito costumeiro e do direito scientifico, identidade que é o signal caracteristico dos tempos modernos... Si um processo fôr submettido a um homem que não estudou o direito, este homem 'pronunciar-se-ha conforme uma vista confusa do negocio em seu complexo e, si juntar á boa fé um caracter decidido, acreditar-se-ha seguro da justiça de sua decisão; mas, o magistrado instruido, o homem da sciencia, tranquilliza a sua consciencia pelo sentimento da justiça sómente depois que consegue "particularizar a relação do direito, discernir as regras que a dominam $\mathrm{e}$ levantar todas as incertezas que obscurecem os elementos da decisão».

12. Entretanto, essa autoridade dos arestos deve ser contida em seus justos limites. Houve um tempo em que, no fôro portuguez, tal foi o prestigio dos casos julgados, que tornou-se necessario reagir. Este prestigio principiou quando AnTonio DA Gama, por ordem d'El-Rei D. Sebastião, substanciou as decisões da Casa de Supplicação; a compilação de Gama foi depois continuada por Phebo, Cabedo, Mendes e Gabriel Pereira, aos quaes o professor Rocha Peniz, na Introducção á pratica formiularia, denominou-pro- 
motores da Escola dos Casos Fulgados; FrançA, nas addições a MEndes, accrescentou a collecção. Tres eram as escolas que discutiam a autoridade dos Casos Fulgados: uns entendiam que não ha autoridade mais respeitavel do que a dos decisionistas e que um ponto de direito, julgado por um aresto, não deveria mais ser posto em duvida; outros entendiam que os decisionistas são guias pouco seguros, porque o jurisconsulto, prendendo-se aos arestos, esquecerá os principios e as leis e paralyzará o estudo das instituições de direito; outros, emfim, adoptando o meio termo, en. tendem que a jurispiudencia dos arestos é excellente guia, quando a série delles é longa, decidindo o ponto de direito sempre do mesmo modo, perpetuo similiter judicatis, mas que toda a attenção deve ser prestada á paridade e á analogia das circumstancias do facto julgado pelo aresto e do facto a julgar-se segundo o aresto. A proposito destas escolas diz ЕschвACH: «Ha homens da lei que, repletos de uma céga deferencia pela jurisprudenciu dos arestos, humilham servilmente sua razão diante das decisões judiciarias; ha, ao con trario, jurisconsultos que, em soberbo desprezo pela pratica, excluem o conhecimento dos arestos da sciencia do direito. Inter utrumque tene: si um aresto repousa sobre uma solida e nervosa argumentação, si encerra uma luminosa demonstração de um problema juridico, dae a essa decisão a autoridade que merece uma consulta bem respondida; é força ainda reconhecer que, quando, no silencio, obscuridade ou insufficiencia da lei, os tribunaes têm decidido certas questões de direito de maneira uniforme e por uma longa série de arestos, esta jurisprudencia passa de algum modo a constituir costume juridico e torna-se supplemento da legislação: e, comtudo, nada de confiança excessiva nas decisões judiciarias: non exemplis sed legibus judicandum est». Ha um trecho de Savigny que não só 
explica a autoridade dos arestos no mesmo tribunal que os proferiu, como a maior influencia dos arestos dos tribunaes superiores: "Affirmam que um tribunal, depois de ter proferido muitas decisø̃es uniformes, está ligado por essas decisões e obrigado a seguir a mesma regra para o futuro. Esta asserção tem o seu lado de verdade, porque os julgamentos anteriores de um tribunal são para elle uma autoridade: é mais digno e mais util seguil-os do que mudal-os levianamente e aqui, como para todos os costumes, age a lei da continuidade; mas, si um exame sério e profundo vem descobrir argumentos até então desconhecidos, o abandono da regra não deverá ser censurado. A influencia exercida pelas decisões dos magistrados superiores sobre os inferiores-tem outro fundamento, porque, independentemente de sua autoridade moral, aquelles magistrados têm o poder de fazer triumphar as suas doutrinas pela reforma das decisões dos juizes subalternos; portanto, quando estes se conformam á jurisprudencia de uma magistratura mais elevada, não cedem á autoridade moral sómente, entram no espirito do legislador que, em sua sabedoria, estabeleceu os diversos gráos de jurisdicção.»

13. Attribuem ao celebre magistrado francez De THov a seguinte maxima: Les arrêts sont bons pour ceux qui les obtiennent. Esta maxima que, á primeira vista, parece ser a critica do arbitrio na administração da justiça, exprime um exacto conhecimento do valor dos casos julgados, isto e, significa que uma decisão, justa em uma causa, póde deixar de sel-o em causa apparentemente identica, mas cujas particularidades podem alterar a situação juridica. Modica circumstancia facti inducit magnam diversitatem juris, dizia Dumoulin. E o citado Dupin, por suas consideraçoes sobre a maxima $\mathrm{DE}$ THOU, demonstra como 
um aresto póde ser bom em um sentido e mau em outro: póde ser mau por má apreciação do facto, sem que, entretanto, tenha havido erro nas conclusões de direito; póde ser errado nas conclusøes de direito e, entretanto, justo na apreciação do facto e até mesmo na decisão. Coglrolo, no prefacio do Annuario critico da jurisprudencia italiana, censura-l'uso molto errato di trascurare il fatto di ogni sentenza per cavarne solo la massima; pois, não só por inexacta como por incompleta apreciação do facto, póde-se dar o caso de uma maxima ou these ser verdadeira porém não applicavel.

14. Em França havia antigamente uns arestos chamados arestos de equidade, que eram aquelles em que os tribunaes pretendiam julgar conforme a equidade natural em opposição á lei; isto deu lugar a tantas injustiças que, tendo ficado proverbial a maxima-Deus nos livre da equidade dos tribunaes, os legisladores tiveram de fixar regras para essa equidade, creando a ficção da equidade civil e, por fim, determinaram que não era licito ao juiz sinão julgar conforme a lei. Já se vê que esses arestos de equidade não tinham autoridade alguma, porque nada mais eram do que a consagração do arbitrio e, por sua natureza, julgamentos de excepção. Não se confunda essa equité dos francezes com a equity dos inglezes. $\mathrm{Na}$ Inglaterra havia duas jurisdicções parallelas e rivaes, obedecendo a principios absolutamente differentes e, como consequencia, dois direitos distinctos e, ás vezes, contradictorios: a common law de um lado, a equity de outro. "E' assás difficil, diz LEHR, determinar o dominio destes dois direitos, porque, menos em virtude de um principio racional do que por circumstancias ou accidentes historicos, operou-se essa divisão de jurisdicções. Só pela enumeração dos ne- 
gocios em que a Côrte da Chancellaria intervinha com exclusão dos outros tribunaes, poder-se-ha determinar os casos de equity e os casos de common law.

15. Isto serve para demonstrar a força dos arestos no systema do direito inglez. Comoé sabido, as fontes do direito inglez são a statute law (legislação) e a common law (costumes e tambem, segundo alguns, as cartas e assentos das côrtes dos antigos reis normandos). Ora, estes costumes são definidos nos julgamentos, de sorte que, no direito inglez mais do que em qualquer outro, a jurisprudencia dos arestos tem grande influencia. Os arestos inglezes são colleccionados em records e em reports: os records são as compilações das deliberações e sentenças dos tribunaes, especialmente das jurisdicções reaes, compilações estas que remontam á mais alta antiguidade e são muito volumosas; os reports não têm por objecto dar o texto official dos julgamentos, mas destacam, nos negocios tratados perante os tribunaes, os pontos de facto e de direito uteis para precisar a jurisprudencia. Esta incumbencia era dada a funccionarios publicos especiaes, nomeados e retribuidos para isso, e que consignavam, nos Yearsbooks ou annuarios, os seus reports. Nos ultimos annos de Henrique VIII desappareceram os reporters officiaes e a jurisprudencia passou a ser compilada por juristas sem mandato publico, entre os quaes se contam jurisconsultos celebres, taes como Dyer, Plownen, Coke e outros. Mas, a incontestavel superioridade da influencia da common law, dos costumes, no direito inglez, vae declinando em vantagem da statute law; e, ultimamente, a creação de uma Côrte Suprema e a fusão da jurisdicção da equity com a do direito commum, «farão desapparecer, diz o citado LeHr, em tempo proximo, a differença entre a common law e a equity e, assim, um dualismo que 
era fonte de complicações sem fim na theoria como na pratica.»

I6. Que os tribunaes dos Estados Unidos da America do Norte recorressem á common law e equity, isto é, aos arestos das cortes inglezas respectivas, é natural; mas, que, segundo dispõe o art. 387 do cit. Decr. n. 848 de I I de Outubro de I 890 , os casos de common law e equity sejam subsidiarios da jurisprudencia e processo federal do Brazil, isso será o cumulo da inoculação . . . . . . . . . . . . . .

... Quando, no seculo XVII, os colonos inglezes se installaram nos paizes chamados por elles Nova Inglaterra e formaram depois os Estados Unidos da America do Norte, trouxeram comsigo as leis da metropole e continuaram a observal-as;-a estas leis, diz Fournier, na sua Introducção ao Codigo do Processo Criminal de New-York, - a estas leis é que os Americanos do Norte dão o nome de common law, de sorte que, como é facil de comprehender, a common law dos Estados Unidos comprehende não só os arestos, isto é, os records e os reports das côrtes inglezas, como tambem a legislação ou estatutos anteriores á fundação das colonias americanas, os quaes, na Inglaterra, são sempre considerados como pertencentes á statute law.' Já se vê que a common law dos Estados Unidos não é a mesma da Inglaterra; e, ainda mais, - a common law não é a mesma em todos os Estados da União: assim, os Estados fundados no seculo XVII, como a Virginia, a Pensilvania, o Massachussets e New-Yok, têm por common law todo o direito inglez, leis e costumes, em tal epocha, ao passo que a common law dos Estados fundados nos seculos XVIII e XIX reflecte $u$ quadro do direito inglez posterior. Em relação á influencia sobre as relações de direito, 
convem notar que, ao envez da Inglaterra, onde prevalece a common law sobre a statute law, nos Estados Unidos prevalece a statute law, isto é, prevalecem as disposições legislativas promulgadas durante a dominação ingleza pelo parlamento britanico ou pelas assembléas coloniaes e, sobretudo, os actos legislativos posteriores á proclamação da independencia. A common law, nos Estados Unidos, vae perdendo terreno, e da equity, então já nem se falla: como, pois abandonar o nosso direito subsidiario, tão perfeitamente determinado pela Lei de i 8 de Agosto de I769, como renegar os costumes da nossa raça, os estylos do nosso fôro, os arestos dos nossos tribunaes, para declarar especialmente subsidiarios «os estatutos que regem as relações juridicas na Republica dos Estados Unidos da America do Norte, os casos de common law e equity», casos estes que nada mais são do que arestos de tribunaes, arestos que, só por força do tradicionalismo da raça ingleza, têm efficacia juridica e que, mesmo na Inglaterra e nos Estados Unidos, vão perdendo a influencia?........... 


\title{
CAPITUTO III
}

\author{
Summario.-Os arestographos.-Os decisionistas.- \\ As revistas de jurisprudencia.-As synopses \\ dos arestos.-Cautelas relativas á autenticidade \\ e integridade dos arestos.-Regras para a boa \\ compilação dos arestos.-Regras para a cita- \\ ção dos arestos.
}

17. Os francezes denominam - arrêtistes - os juristas que compilam arestos e fazem, em summario, a enumeração dos pontos de direito nelles decididos. Não falta quem queira aportuguezar essa palavra, creando o termo aretista; mas, parece-nos melhor a palavra-arestographo, por estar mais de accordo com a pronuncia e com as origens da nossa lingua. Nem a palavra-arretista - é encontrada nos nossos bons diccionarios; nestes encontra-se a palavra-aresteiropara significar, não o compilador de arestos, sim o advogado que tem a mania de fundar os seus assertos sómente em arestos, desprezando os principios da sciencia e as leis. Mas, a verdade é que o gosto da compilação dos arestos mais se accentuou entre os juristas francezes do que em qualquer outro paiz, a tal ponto que, em França, as primeiras obras de direito não foram sinão Estylos do fôro e Collecçôes de arestos. 


\section{$-32-$}

Taes compilações se multiplicavam, umas organisadas por ordem de datas, outras por ordem alphabetica, outras por ordem de materias, de modo tal que Maussac lamentava que a arte typographica, em sua epocha, parecia exclusivamente reservada «a perpetuar as futeis rapsodias dos collecionadores de arestos, em prejuizo doutas lucubrações dos sabios»: não havia mesmo tribunal de departamento que não tivesse o seu arestographo. E a proposito, conta o citado Dupin que, quando revia as provas da primeira edição do seu opusculo, estava composto arestophago por arestographo: «confesso, diz elle, que tive impetos de não corrigir, porque esses compiladores eram, em sua maxima parte, moins en effet des descripteurs que des croqueurs d'arrêts» Bem se vê que essa critica não attinge a arestographos da estatura por exemplo, de MERLIN e Dalloz, em França, de Cogliolo e Chironi, na Italia, e de Plowden e Coke, na Inglaterra.

I 8. Os jurisconsultos portuguezes que compilavam arestos-são chamados decisionistas. Os decisionistas, em geral não transcreviam o texto das sentenças e accordams; substanciavam as decisões, quasi á semelhança dos reports inglezes, destacando, em titulo mais saliente, a these ou questão principal, expondo, em summario, as questões dependentes e as razões de decidir; e, no contexto, proposto o caso, seguia-se a salientação das duvidas, a exposição dos argumentos e as soluções. Alguns trazem addições em fórma de scholio e a critica com remissões aos Doutores; fazem, no intitulado, remissões ás Leis Romanas ou ás Ordenações, cuja intelligencia foi objecto de ponto duvidoso; outros indicam, no fim da decisão, o processo, os autos, as partes que litigaram e o escrivão que funccionou; outros, além da critica das decisões, trazem o texto dos Accordams. Assim: Gama substan- 
ciou 393 decisões da Casa de Supplicação de Lisboa, as quaes foram depois publicadas com addições de Dias de Mena; Alvaro Valasco publicou i95 consultas e decisões, referindo-se aos casos julgados; $\mathrm{CAL}_{\mathrm{AL}}$ DAS expõe 53 questões forenses; Thomé VaLAsco traz IOO decisões; REynoso collige observações em que se refere a muitos casos julgados; Gabriel Pereira substanciou I 29 decisőes da Casa de Supplicação, não esquecendo de referir-se, em todas, á Ordenação respectiva; MACEDo traz, segundo o systema de GABriel Pereira, i i 7 decisões desse mesmo tribunal, com referencia não só ás Ordenações, como ás Leis Romanas; Themudo traz 349 decisões da Relação Metropolitana de Lisboa; Arouca, em forma de allegações, traz I I 2 consultas e soluções; Guerreiro, traz soluções, etc. Mas, propriamente, os textos dos arestos, em sua integra, encontram-se em CABEDo, que traz 2 I 4 decisões na parte primeira e I 20 na segunda; em Phebo, que traz 24 decisões da Casa de Supplicação; em Mendes, na Pratica Lusitana, e no seu annotador França; em Pegas, nos Forenses e no tomo XV dos Comm. Os decisionistas escreviam em latim; mas, quando transcreviam os arestos, mantinham a lingua portugueza quanto ao texto desses mesmos arestos. $\mathrm{O}$ senador Candido Mendes, no Auxiliar Furidico, pags. 335 e seguintes, reuniu, sob o tituloArestos da Casa de Supplicação, differentes arestos dos que colleccionaram Cabedo, Phebo e França e que têm ainda interesse para o nosso fôro; $e$, ainda em 1885, colligiu textualmente e em ordem chronologica os Arestos do Supremo Tribunal de Fustiça, desde I 829 até I 883 , sendo que esta compilação foi concluida pelo Doutor Fernando Mendes, com dous indices-um chronologico e outro alphabetico. Os jornaes e revistas de jurisprudencia, taes, como, contemporaneamente, o Direito, sob a direcção do Dou- 


\section{$-34-$}

tor J. J. do Monte, a Gazeta Furidica, do Doutor C. PERDigão, se têm incumbido de publicar os arestos dos nossos tribunaes; e nos Estados, vae actualmente se desenvolvendo o gosto das revistas de jurisprudencia, não só para a publicação de arestos, como para a doutrina e legislação. O Supremo Tribunal Federal, assim como os tribunaes de varios Estados, têm mesmo publicação official, em compilação, trazendo indistinctamente, por ordem chronologica, todos os Accordams do Tribunal, quer os que constituem arestos, quer os que ainda pendem de embargos ou de outro recurso.

19. O uso actual, pois, é transcrever integralmente o aresto, precedendo-o de uma synopse. $O$ arestographo, para compor essa synopse, tem necessidade de um trabalho de analyse ou resolução do aresto; mas, este trabalho preparatorio é latente e o seu fim é preparar elementos para uma concentração logica das razões de decidir e para a construcção systematica dos pontos decididos. $\mathrm{Na}$ synopse de um aresto não são estabelecidas as soluções indissoluvelmente e sómente ligadas ao facto, mas as theses que resultam da aroumentação demonstrativa dos juizes. Por outro lado, o arestographo não precisa extrahir dos arestos os principios indiscutiveis, os preceitos expressos em lei, devendo limitar-se a extrahir as razões de decidir e os pontos decididos: tudo depende de uma certa penetração para a analyse e de um tino especial para a synthese. A expressão-synopse, do grego syn (com, junto) e opsis (vista), suppõe um summario que permitta, de um golpe de vista, perceber quaes sejam as questões decididas no aresto; ora, para isso não é preciso encher o summario de principios geraes e de preceitos expressos na lei, os quaes, sómente pela necessidade de organizar os argumentos, os juizes os repetem na redacção das sentenças ou 
accordams. A connexão entre os principios geraes e a lei-constitue a ratio legis; a connexão entre os principios geraes, a lei e a relação de direito litigiosa-constitue a razão de decidir. Uma cousa é a razão da lei, outra cousa é a razão da applicação dia lei a um facto. A expressão-ratio legis-se applica ao passado e ao futuro, ao passo que a expressão - razâo de decidir-se applica ao presente. A expressão-ratio legis, applicada ao passado, designa a regra superior deduzida dos principios geraes de direito; applicada ao futuro, designa o effeito que a lei é destinada a produzir, isto é, o fim, a intenção do legislador; e, neste ultimo sentido, como na apreciação de um caso particular presente trata-se de verificar sempre si o fim da lei é preenchido, neste ultimo sentido a ratio legis confunde-se com a razão de decidir, que se póde definir-o argumento pelo qual se mostra que, na decisão de um caso presente, é preenchido $o$ fim da lei, a intenção do legislador. Já se deixa ver que, na synopse dos arestos, é excusado reproduzir os principios geraes que serviram para a argumentação, bastando summariar as razões de decidir na especie.

20. Quer recorrendo aos registros dos tribunaes, quer recorrendo aos autos ou originaes dos arestos, convém que o compilador, além dessa garantia da autenticidade, attenda para o requisito da integridade, de sorte que o aresto não seja mutilado, nem corrompido por ernendas, entrelinhas, riscos e rasuras não resalvados, assim como por interpolações e pelo mais que duvida faça. A impressão deve merecer o maximo cuidado no tocante á revisão; pois, muitas vezes a troca de uma lettra basta para o transtorno do argumento e mesmo de uma proposição que possa ser util para a synopse e para os interessados. Quem se dispuzer a fazer taes compilações-comprehenda o 
alcance de sua responsabilidade moral; lembre-se de que o serviço é da maxima importancia; lembre-se do celebre arestographo JEAN BACQUET, cuja reputação foi maior depois de sua morte do que em vida, diz Lorsel, porque, advogando inuito pouco, era assiduo ás audiencias e sessões dos tribunaes, manifestando rigoroso escrupulo na construcção das synopses e na reproducção dos arestos.

2I. Vamos agora extrahir dos aphorismos de Bacon DE Verulamio as regras para a boa compilação dos arestos; justo é que um jurisconsulto da Inglaterra onde os records e os reports tanta influencia exercem, nos forneça essas regras. -I. Os arestos devem ser escolhidos d'entre os proferidos ern tempos calmos e moderados e não em epochas de tyrannia, de faç̧ões e de desordens, porque os destas epochas magis nocent quant docent (aph. 22).--II. Os arestos recentes são mais seguros do que os antigos (aph. 23).-III. Importa muito verificar a publicidade e solemnidade com que foram proferidos os arestos, porque os arestos são como a agua, quanto mais corrente tanto mais saudavel: exempla enim sicut acqua, in profluente sanissima (aph. 28.) - V. Os arestos devem ser extrahidos dos autos originaes e não dos livros dos historiadores (aph. 30)-VI. Os arestos devem ser dispostos segundo a ordem dos tempos e não segundo a ordem das materias, porque a meditação sobre a epocha do julgado muita luz dá ao juiz prudente (aph. 76). VII. Os arestos desacreditados, por proferidos sob a pressão de notorios motivos inconfessaveis, devem ser rejeitados. -VIII. Na synopse dos arestos não é licito sahir da especie decidida, ampliando-o sob pretexto de analogia, sendo preferivel, na duvida, restringil-o, para evitar aquella critica de D'Aguesseau ás com- 


\section{$-37-$}

pilaçбes deste genero, «cujo caracter commum, diz elle, é ter maior autoridade de longe do que de perto».

22. Passemos agora ás regras a observar na citação dos arestos; e para isso aproveitaremos muiţo das regras do citado Dupin, traduzidas pelo senador Candido Mendes, no Auxiliar Furidico.-I. Não se deve citar arestos senão em falta de lei precisa. II. Antes de citar arestos, convém examinar todos os que existem sobre a mesma especie.-III. Não basta ter examinado os arestos em uma só compilação, é mister conferir os das outras; algumas vezes não basta conferir as compilações e convém recorrer aos originaes ou aos registros.-IV. No caso de divergencia entre diversas compilações, convém attender si o compilador era advogado ou juiz na causa e si, por acaso, não existe alguma razão que decida da preferencia entre as decisões. - V. Convém desconfiar sempre das synopses, dos summarios e das criticas. VI. Não basta citar um só aresto para deduzir jurisprudencia firmada.-VII. Quem cita um aresto deve mostrar a identidade das especies; quem nega a applicação de um aresto deve demonstrar as differenças. -.VIII. Demonstrada a applicação de um aresto, é util salientar-lhe a importancia pela indicação dos nomes dos advogados que pleitearam a causa decidida, dos juizes que o proferiram, do relator do feito e do accordam, assim como pela celebridade do tribunal, e pela solemnidade e publicidade da discussão e conferencia.-IX. Entre muitos arestos, convém preferir os 
dos tribunaes mais elevados. -X. Quando existem arestos oppostos, é mister concilial-os, sendo possivel ; ou, então, demonstrar quaes foram os que melhor e mais acertadamente decidiram a questão.-XI. Quem considera arestos os accordams não fundamentados que reformam sentenças, é obrigado a demonstrar que o aresto não incorre na critica de Ulpiano, Dig. L. I, de appeltat.:-Nonnunquam benè latas sententias in pejus reformant. 


\title{
TITULO II
}

\section{Estylos, usos e costumes do fôro}

\section{CAPITULO I}

\author{
Summario.-Definição.-Causa efficiente dos estylos \\ do fôro.-Requisitos.-Divisão.-Prova.-Ef- \\ feitos.-Efficacia._Collecções.-A Ord. L. III, \\ tit. LXIV; a Carta Regia de 7 de Junho de \\ I $605, \S 8 .^{\circ}$; a Lei de 18 de Agosto de I 769 , \\ $\S$ 14.-Os estylos do fóro no actual regimen.
}

1. Estylo do fôro é o costume judicial determinando o modo e a fórma de proceder que devem ser observados no fôro.

Costume judicial, para distinguir do costume, isto é, do costume que regula relações de direito material; costume judicial, porque se applica sómente aos actos que são exercidos ou inspeccionados pela autoridade decisoria ou ordinatoria do juiz; costume judicial, porque concerne ao modo e á forma por que devem ser propostas as causas em juizo, ás cautelas, formalidades e solemnidades com que devem ser la- 
vrados os actos do expediente dos feitos e, em geral, dos instrumentos publicos, cujo destino é sempre a prova judicial.

Modo e forma de proceder: modo é a delimitação dos principios productores do acto forense, quer os materiaes, como a dimensão e disposição do papel, livros, condições da palavra fallada e escripta, etc., quer os efficientes, como a qualidade, quantidade, concurso, situação, habito e, em geral, as condições do exercicio dos agentes, movimento destes no tempo e no espaço, e ordem dos actos. Forma, no presente caso, não se refere á forma intrinseca, mas ao exemplar ou forma extrinseca ou litteral dos actos forenses, quer do fôro judicial (acta causa e acta judicii) quer do fôro extrajudicial, escripturas, instrumentos, registros, protestos e autenticaçð̄es.

Que devem ser observados no fôro, tanto no fôro judicial perante os tribunaes, juizes singulares, escrivães e mais officiaes do juizo, como no fôro extrajudicial perante os tabelliães e officiaes de registros e protestos. Estes actos extrajudiciaes são aliás judiciaes, si não por intervenção, ao menos por inspecção, visto que se acham sob a fiscalisação do juiz, a quem os tabelliães e officiaes dirigem consultas e a quem as partes dirigem reclamações.

2. Os estylos do fôro podem ser introduzidos pelos tribunaes e, em alguns casos, pelos juizes singulares, sempre, porém tendentes, não a fazer lei, mas a declarar e tornar exequiveis, no modo e na forma, as leis do processo. Os advogados e solicitadores, em seus trabalhos, podem provocar a introducção de estylos, mas nunca podem, por si, firmal-os. Os escrivães, nos acta judicii, taes como as citações, as notificações, os termos, os autos, as assentadas, podem 
usar de um estylo singular desde que o juiz, sciente e paciente, o admitta; mas, não podem, por si, introduzil-o como estylo do fôro. Os tabelliães, no lavrar das escripturas e instrumentos, na confecção das cedulas impressas de procurações, etc., podem usar da redacção que melhor lhes pareça: mas, sempre de accordo com as cautelas legaes e jámais com a pretenção de introduzil-a como estylo do fôro.

3. Bem se vê que o estylo do fôro não póde ser introduzido por lei; pois, havendo lei, ipso facto deixa de ser um estylo e torna-se um preceito legal. $O$ estylo, como dissemos, serve para declarar o modo e a forma de tornar exequivel no fôro uma lei de processo; e suppõe: a) consenso tacito do povo, imitando-o ou não contrariando, isto é, o consenso tacito de todos os funccionarios e-auxiliares da justiça; b) frequencia dos actos, posto que alguns Doutores entendam que basta um acto acceito sem contradicção, para que se introduza o estylo do fôro; c) diuturnidade de tempo, entendendo alguns Doutores que esta diuturnidade consiste no lapso de dez annos, entendendo outros que a determinação deste tempo deve ficar ao prudente arbitrio do juiz.

4. O estylo do fôro póde ser interpretativo, abrogativo ou introductivo. Interpretativo, quando declara alguma lei ou costume processual; abrogativo, quando abroga algum uso até então recebido ou contraría algum estylo anteriormente introduzido: introductizio quando introduz algum estylo novo, não contra, porém além de algum estylo até então recebido. No primeiro caso, pensam os Doutores que o numero de actos deve ser deixado ao prudente arbitrio do juiz; no terceiro caso, pensam, alguns que é necessario mais de um acto. 
5. Os estylos do fôro, si os considerarmos em sua introducção, devem ser provados pela inducção de factos e actos judiciaes: como factos, non presumi sed probanda esse, salvo quando forem notorios; e, si houver duvida sobre a notoriedade, póde o juiz informar-se dos praticos, advogados, escrivães e tabelliães. Os estylos do fôro podem ser provados tambem por meio de testemunhas que exprimam a exacta razão de sua sciencia e, bem assim, por meio de instrumentos, pela inspecção e comparação dos autos redigidos. O Assento de 27 de Novembro de I 7 I diz que o estylo antigo e com os requisitos necessarios, provado pelo depoimento dos Escrivães da Casa, chamados para isso á Mesa, têm força não só para interpretar mas para revogar a Lei, principalmente si são relativos ao ordinatorio, não ao decisorio dos processos.

6. Para que o estylo do foro tenha o effeito de annullar os actos judiciaes feitos em contrario a elles, é preciso: a) que seja certo e invariavel; b) que seja inveterado; c) que seja concernente á razão ou ordem do processo e não sómente á norma dos escriptos; d) que revistam as condições necessarias para ter força da lei.

7. Os estylos não se estendem de um fôro a outro fôro, porque não obrigam geralmente, mas apenas perante o tribunal, juizo ou fôro onde foram introduzidos e recebidos: Stylus pro lege servatur in eo loco ubi viget. A Ord. L. III, tit. LXIV dispõe que «quando algum caso fôr trazido em pratica, que seja determinado por alguma Lei de nossos Reinos, ou estylo de nossa Côrte, de costume que nos ditos Reinos, ou em cada uma parte longamente usado, e tal que por Direito se deva guardar, seja por elles julgado sem embargo do que as Leis Imperiaes acerca do dito caso 
em outra maneira dispð̌em: porque onde a Lei, stylo ou costume dos nossos Reinos dispõem, cessem todas as outras Leis e Direito.» Por stylos da côrte se entendem os da Casa de Supplicação de Lisboa. Os da Casa do Porto se mandavam guardar na Casa de Supplicação emquanto applicaveis; e as Cartas Regias de 16 de Junho de 1600 e de 3 de Agosto de I643, assim como o Assento de Io de Março de I640, determinaram que as duas Casas conformassem os seus emquanto possivel e cada uma conservasse os seus. Os estylos particulares das Relações, segundo expressa disposição do Assento de i 3 de Fevereiro de I 755, sendo exorbitantes das regras de direito, não podem estender-se a outros lugares.

8. Os estylos da Casa de Supplicação foram colligidos por Costa, por Pegas, por Solano, por BoRges Carneiro, assim como os da Casa do Porto, coordenados estes pelo governador dessa Casa, Henrique de Souza. Na obra do primeiro, João Martins da Costa, a qual se intitula-De stylis, vêm taes estylos, á pag. I 78 e á pag. 2 I9. Os praxistas dão essa colleçção de estylos, de uma e de outra, como tendo sido feita em i6 I 2. No Auxiliar furidico, do senador Candido Mendes, de pag. 67 á pag. 70, estão os Estylos da Casa de Supplicação; de pag. 7 I á pag. 83 estão os Estylos da Casa do Porto; de pag. 84 a pag. Io3 estão os Estylos da Casa de Supplicação $e$ do Porto, systematisados por Borges Carneiro, com a situação dos lugares em que se acham em PEGAS e com a observação de que muitos desses estylos se acham hoje reduzidos a diveito escripto ou alterados por Assentos e Determinações Reaes; de pag. io3 á pag. I 5 estão os Estylos da Casa de Supplicação, compilados por CABEDo; e, por fim, está o Estylo sobre os recursos á Coroa, compilado por João Martins da Costa. 
9. Os estylos do fôro podem ser mudados ou revogados por lei e reiteraçăo de actos em contrario que formem um estylo abrogativo. A Carta Regia de 7 de Junho de $1605, \S 8$, porém, assim dispunha: «E porque convem e importa muito que os estylos antigos da Casa de Supplicação se guardem, sem se permittir introduzirem-se outros de novo, nem praticas particulares assim no despacho dos feitos, como no fazer das audiencias, encommendo e encarrego muito ao Regedor e Chanceller della que procurem saber e averiguar bem quaes são os ditos estylos antigos; e informando-se para isso dos Officiaes de mais pratica e experjencia; e que os façam inviolavelmente guardar e conservar; e que movendo-se sobre elles alguma duvida ou alteração, ouvidos os Ministros antigos da dita Casa, e ainda os que servirem de fóra della, que delles tenham conhecimento, se tome na Mesa grande, perante o Regedor, a resolução que parecer que mais convém á boa administração da justiça; e se faça disto Assento no Livro da Relação, para d'ahi em diante se guardar assim e se não tornar a dar na mesma duvida.» Referindo-se a esta Carta Regia, a Lei de I 8 de Agosto de I 769, § 5., determinou que «as interpretações ou transgressões dos estylos da Casa de Supplicação nelle estabelecidos por Assentos tomados na forma, que para elles está determinada, sejarn da mesma sorte observados como Leis: excitando a pratica de levar o Chanceller as Cartas e Sentenças, em que elles foram offendidos, com as suas glosas á presença do Regedor, para elle mandar proceder na mesma conformidade acima ordenada: e ordenando que em todos os casos de Assentos sejam convocados por Avisos do Guardamór da Relação os Ministros de fóra della, que ao Regedor parecer convocar.» $E$ o $\S$ I4 da mesina Lei, explicando a Ord. L. III, tit. LXIV, que mandou 
observar os estylos da Côrte, declarou que os estylos da Côrte devem ser sómente os que se acharem es. tabelecidos e approvados por Assento da Casa de Supplicação.

10. Por ahi se vê, que para ter força de Lei, era preciso: a) que os estylos fossem da Casa de Supplicação de Lisbôa, porque das outras relações, não são estylos da Corte; b) que tivessem sido confirmados por Assentos. Portanto, diz o citado CorrêAa Telles, «é de nenhum uso o que disse Pegas, no Com. á Ord. Liv. I, tit. I, $\S 37$, n. I 3, que os estylos devem ter sido observados por mais de dez annos para se deverem guardar. Nunca obrigam com força de lei, emquanto não estão, não pode o Chanceller glosar sentença alguma, sob pretexto de ser contraria a estylo. E visto que a maior parte dos estylos, que compilou João Martins da Costa não estão confirmados por Assentos, não thes attribuo maior autoridade, que a dou á Pratica de Mendes ou outro qualquer praxista. Quando, pois, algum Desembargador da Casa de Supplicação quizer fundar-se em estylo, que não esteja tomado por Assento, deverá primeiro requerel-o ao Regedor. E si o Chanceller vir sentença fundada em tal estylo, pode glosal-a, afim de que se tome Assento, que confirme ou reprove esse estylo. E si os estylos antes de confirmados não têm força de Lei, será barbaridade condemnar alguem pela inobservancia delles, porque pena sem Lei é effeito sem causa». Por isso, Borges Carnetro chegou a affirmar que «os estylos mais se devem hoje considerar como direito escripto».

11. Era esse o direito antigo, que já vigorava antes da proclamação da Republica, isto é, no tempo do-Imperio; e, como nenhum dos tribunaes brazilei- 
ros tinha usado das attribuições da Casa de Supplicação de Lisboa, não havia outros estylos com força de Lei senão os confirmados por Assentos da dita Casa de Supplicação. E' certo que os Decrs. n. 2684. de 23 de Outubro de 1875 e n. 6142 de ro de Março de 1876 --deram ao Supremo Tribunal de Justiça a attribuição de tomar Assentos com força de lei, á semelhança das attribuições que a Ord. L. I, tit. V., $\S 5 .^{\circ}$ e a Lei de 18 de Agosto de $1769, \S 4 .^{\circ}$ - tinham dado á Casa de Supplicação de Lisbôa; mas, não consta estylo aloum tomado por Assento do Supremo Tribunal de Justiça e, actualmente, estabelecida a dualidade de soberania, que pretendem ser uma consequencia do regimen actual, e a competencia dos Estados para legislar sobre o processo, podem os Tribunaes de Justiça dos Estados chamar a si a competencia de determinar estylos do fôro com força de lei? Parece-nos que, si nas leis de organisação judiciaria do Estado, não fôr dada essa competencia ao Tribunal Superior, não póde este chamar a si a attribuição de tomar taes Assentos; prevalecem, portanto, as regras geraes estabelecidas no n. 4 deste estudo para a introducção dos estylos, isto é, o consenso tacito dos funccionarios e auxiliares da justiça, a frequencia dos actos e a diuturnidade do tempo, a qual, segundo o entender de PECAs e mais reinicolas, sempre seguidos, consiste no lapso de dez annos. As novas leis de processo exigem naturalmente novos usos, novas observancias, sobre o modo e forma de pratical-as. Os estylos antigos, com força de lei, são sómente os confirmados por Assentos da Casa de Supplicação e, como diz Borges Carneiro, se devem hoje considerar como direito escripto: os estylos novos ainda se estão formando. Seria de grande alcance que os tribunaes, os juizes, os escrivães e tabelliães antigos, os advogados exercitados-tratassem de colli 
gir os usos e praticas mais frequentes, «assim no despacho dos feitos como no fazer das audiencias», afim de ser organisada e systematisada uma boa recopilação de estylos do fôro, tendo em vista as novas leis do processo e as clausulas e cautelas que exigem o progresso e desenvolvimento das relações de direito no lavrar dos actos e contractos, dos termos e autos, e, em geral, de todos os instrumentos, quer originaes quer extrahidos. 


\title{
CAPITULO II
}

\author{
SUMmario.-Differença entre o estylo, o costume e o \\ uso.-Rito e Observancia. - Uso commercial e \\ Costume geral.
}

12. Do que fica exposto, vemos que o objecto do estylo do fôro é o modo e a forma de proceder, fallar e escrever em juizo e em tudo o que se acha sob a inspecção do juizo. "Chama-se estylo, diz CorRÊA Telles, no Commentario à Lei da Boa Razão, n. 22, O uso acerca de praticar o que as Leis mandam. Por exemplo, é estylo quando, julgada uma liquidação, continúa a execução nos autos da liquidação, sem se extrahir delles outra sentença... Parece, continúa o citado jurisconsulto, no n. I97, que o es. tylo não differe do costume sinão no objecto: este respeita ao modo de julgar, aquelle ao modo de ordenar e processo. O estylo é relativo á pratica do direito; o costume é uma parte do mesmo direito».

13. Feita a distincção entre o estylo e o costume, convém-agora distinguir o estylo e o costume-dos usos. O costume regula relações de direito, ou antes, é uma parte do mesmo direito objectivo; e dados os 
requisitos do $\S$ I4 da Lei de I 8 de Agosto dé I 769 , de ser conforme á boa razão, de não ser contrario á Lei e de ser tão antigo que exceda de cem annos, tal costume tem força de lei, nos termos da Ord. L. III, tit. LXIV. O uso é a série longa de factos, da qual póde-resultar o costume, si taes factos consistem em regular ou reger relações de direito, e o estylo, si os factos consistem em reger o modo e a forma de assegurar essas relações no fôro.

14. Na technica forense antiga, eram ainda empregadas as palavras - rito e observancia. O rito suppunha. solemnidades annexas ao symbolismo juridico e, portanto, já não tem actualidade. A observancia não distingue-se do estylo quanto ao objecto: entendiam alguns que o estylo se applicava mais ás praticas do fôro judicial, ao passo que a observancia se applicava ás praticas do fôro extrajudicial; outros entendiam que a palavra observancia significava as praticas da vida em quaesquer relações sociaes exercidas fóra da acção dos funccionarios forenses, judiciaes ou extrajudiciaes; outros, e é a significação actual, entendem que observancia se applica ás praticas das repartições administrativas e ás praticas das corporações e classes de pessoas.

15. Na legislação mercantil encontram-se as expressões-usos commerciaes e costume geval. Estas expressões têm o seu sentido especial; e, para fixal-o, precisamos desde logo notar que uma cousa é o uso commercial, outra cousa é o costume geval. Confira-se o Dec. n. 737 de 25 de Novembro de i85o, arts. 216 a $22 \mathrm{I}$. O uso commercial é a série longa de normas que, na falta de lei ou disposição de contracto, são ordinariamente adoptadas, no commercio, para regular relações de direito e casos de pratica 
mercantil das praças, districtos e lugares commerciaes; o costume geral é a série longa de normas que, na falta de lei ou disposição de contracto, são ordinariamente adoptadas, no commercio, para regular relações de direito e casos da pratica, não só das praças, districtos e lugares commerciaes, como de outros quaesquer logares. Para fixação e prova dos usos commerciaes, a lei exige assentos ou attestados das Juntas Commerciaes; e, nos casos em que a lei permitte recorrer aos usos commerciaes dos panzes extrangeiros, quando taes usos já não constam de assento's tomados nas Juntas Commerciaes, devem ser provados por acto autentico do paiz respectivo, acto esse que deve ser legalizado pelo respectivo consul brazileiro. O costume geval, porém, pode ser provado por qualquer genero de prova. O Dec. n. 596 de 19 de Julho de s 890, arts. 30 e 33, regula o modo e a fórma por que devem ser tomados os assentos sobre usos commerciaes. Depois de haverem colligido as praticas e usos commerciaes admittidos nas praças, portos e mais lugares de commercio do seu districto, nos casos em que os mande guardar o Codigo Commercial, ouvindo os corretores e commerciantes mais notaveis e procedendo ás averiguações que julgarem convenientes, as Juntas os farão publicar na folha official com um convite a todos os interessados e pessoas competentes, para que façam sobre elles as observações que se lhes offerecerem, dentro do prazo de tres mezes; e terminado este, declararão verdadeiros os usos commerciaes em favor dos quaes concorrem os requisitos seguintes: ${ }^{\circ} .^{\circ}$ serem conformes aos sãos principios de boa fé e maximas commerciaes e geralmente praticados entre os commerciantes do lugar; 2." não serem contrarios a alguma disposição do Codigo. Commercial ou lei depois delle publicada. A Junta deverá estar completa para essa decisão e desta o assento 
será lavrado em livro para esse fim privativamente destinado, com exposição dos seus fundamentos e declaração dos votos divergentes. Os assentos, assignados por todos os membros da Junta e publicados na folha official, terão, tres mezes depois da publicação, força obrigatoria para a decisão das questões que se suscitarem sobre os usos commerciaes a que se referirem, emquanto não forem revogados por lei. A Junta da Capital Federal, obtendo a collecção de usos commerciaes de toda a Republica, proporá ao ministerio da justiça os que convenha estabelecer por lei geral, afim de serem submettidos ao Congresso, si assim o resolver o Governo. 


\title{
TITULO III
}

\section{Pareceres concordes, opinião commum, formularios}

\author{
SUMmaRio.-Formas da actividade pratica dos juris- \\ tas. - Limites da auctoridade moral dos juristas. - \\ Consultas e respostas. -Formularios officiaes e \\ formularios officiosos. - Litteratura formularia.- \\ Evolução juridica pela generalisação das dispo- \\ siçôes convencionaes.
}

1. CICERo denomina militia urbana a classe dos advogados, tabelliães ou notarios, escrivães e mais auxiliares da justiça; e, quanto aos advogados, essa denominação ficou consagrada pelos Imperadores Leão e Anthemius, na L. I4 do Cod., liv. II, tit. VII, de advocatis diversor. judic., os quaes, demonstrando que os advogados não são menos uteis á sociedade do que os que combatem em defeza da patria, deram-lhes privilegios de militares, que até hoje não foram revogados. Cicero dividiu a actividade pratica dos juristas em tres ramos; respondere, scribere, cavere. Não insistimos pelo valor scientifico dessa enumeração: a nota 96 da cit. obra de JHERING seria sufficiente para destruir qualquer illusão. Mas, ha um ponto que não deve 


\section{$-54-$}

ficar sem attenção especial: na enumeração dessas formas da actividade pratica dos juristas romanos, Cicero colloca em primeiro lugar o acto respondendi, porque em Roma, «os bons officios dos juristas preveniam o damno, ao passo que os do jurista moderno buscam antes reparal-o.» Ora, na investigação desses meios de reparação do direito violado, é onde mais surgem as contestações e as duvidas, de sorte que o officio do jurista-consultor (para nos servirmos do termo dos Estatutos de Coimbra) é muito mais importante para a formação da praxe do que o dos advogados litigando e discutindo em juizo o interesse de seu constituinte. Dir-se-ha que, entrando assim no campo da sciencia, deveriamos tambem classificar, entre as formas organicas da praxe, as locubrações dos tratadistas e commentadores, assim como toda a litteratura juridica; porém, não ha paridade: os pareceres dos advogados e jurisconsultos, tomada a palavra-parecer - no sentido restricto da technica forense, referem-se a um facto particular, a um caso isolado ou a uma singular relação de direito, para a qual não ha regra expressa ou sobre a qual occorre duvida na applicação das regras existentes, de sorte que todo o merito do parecer está em ter attingindo e resolvido o ponto da duvida. Os pareceres não são obras theoricas, ou pelo menos não o devem ser, visto que não têm por objecto o desenvolvimento dos principios e das leis em suas relações geraes, mas sim o exame dos principios e das leis em sua applicação immediata. Ora, sendo os pareceres respostas a consultas relativas a uma singular e individuada relação de direito ou ao modo e forma de realisar e assegurar essa relação, e sendo essas consultas despertadas pela necessidade de esclarecer duvidas occorridas por omissão ou obscuridade da lei, claro está que as soluções dessas duvidas, quando uniformes em pareceres concordes, são manifestações de regras 
latentes no texto das leis ou na consciencia geral, regras latentes essas que são normas que, longamente usadas, vão entrando na formaçăo do direito, depuradas pela pratica constante, posto que sem a mesma autoridade moral dos arestos; pois, além da falta do caracter publico, o jurista-consultor responde, não em vista de provas do facto, mas em vista de simples allegaçẫo do facto. $\mathrm{O}$ jurista-consultor não é testis facti, é testis juris : elle jamais entra na apreciação da verdade do facto, por isso que o acceita nos restrictos termos da consulta; elle dá seu parecer (responsum), mas não defende uma causa (disputatio fori). Estas responsa tiveram extraordinaria influencia na formação do direito romano: Augusto chegou a dar a uma certa classe de jurisconsultos o privilegio de responder em seu nome, e Adriano determinou que, quando os pareceres desses jurisconsultos autorisados fossem unanimes, teriam funç̧ão de lei (legis vicem) para os casos semelhantes, auctoritas que Valentiniano teve de restringir pela celebre constituição chamada lei das citaçôes. Os outros jurisconsultos ficaram com a liberdade de responder ás consultas, mas a sua auctoridade conservou o segundo plano. Esta attribuição de responder de jure, como é logico, não creava dispensa do julgamento em que se deveria decidir de jure et de facto. Nos seculos XIV e XV chegaram mesmo a constituir um novo ramo de litteratura juridica as compilações de consultas e pareceres.

2. No L. II, tit. VI, cap. VIII, n. 4 e seguintes dos Estatutos de Coimbra, encontram-se diversas regras sobre a applicação do direito ao facto, as quaes, por serem communs ás sentenças, não deixam de servir aos que, na pratica forense, se dedicam a responder consultas. Vamos fazer uma resolução ou analyse dessas regras, para evitar que muitos dos nossos jurisconsultos, habeis em longas exposições theoricas e 
em profundas demonstrações scientificas, continuem a suppor que podem, em seus pareceres, abusar de quem apenas lhes pede a solução de uma questão pratica, e envolver, no apparato de suas dissertações, o ponto da duvida. A applicaşão das leis ao facto exige: $-\ll I^{\circ}{ }^{\circ}$ ) Que bem seja comprehendido o caso proposto:-2..0) Que seja explorada a natureza do negocio, de que nelle se trata;-3..$\left.^{\circ}\right)$ Que seja formado o estado da questão:$4^{\circ}$ ) Que se attenda bem em que consiste o ponto da duvida». Portanto, o caso proposto, a natureza do negocio, o estado da questão, o ponto da duvida:-eis o que principalmente deve ser estudado por quem responde a uma consulta. Caso proposto é sempre um facto particular, determinado por circumstancias de pessoas reaes ou figuradas, cousas, tempo, lugar, qualidade, quantidade, situação e habito. Natureza do negocio é a relação de direito e a instituição de direito a que está logicamente sujeita a relação que faz objecto do caso proposto. Estado da questão é a accepção da relação de direito, que faz objecto do caso proposto, nos termos em que se acha, em frente dos meios juridicos de realisal-a ou reintegral-a hic et nunc. Ponto $d a d u$ vida é uma circumstancia que, por minima que seja, torna incerto o direito, ou difficulta a determinação da lei applicavel singularmente e especificadamente ao caso proposto. A resposta nunca póde ser sinão com a clausula - salvo melhor juizo, porque o direito, tanto é difficil, que é estudado nas academias; e ninguem pode ter a pretenção, a menos que seja um vaidoso, um futil, ou um pueril, de não enganar-se nas soluções que dependem da razão limitada do homem: Os consultores não estão incumbidos de agrupar relações de direito nem de demonstrar as regras que dominarn as instituições, pois isso compete aos tratadistas e commentadores e, até certo ponto e dentro de certos limites, aos advogados nos arrazoados; os pareceres devem 
- "particularisar a relação de diveito» $\mathrm{e}$ "discernir as regras que a dominam»: eis tudo.

3. Mas, não eram sómente estas respostas a consultas (responsa) o unico meio da manifestação da communis opinio: a communis opinio referia-se não só ás responsa, como aos preceitos expostos nas obras dogmaticas que tratavam da pratica, do direito e mesmo ás que, comquanto theoricas ou relativas a esclarecer o direito já existente, estabeleciam regras ou doutrinas sobre casos não previstos. Em todo caso, a opinião commum dos jurisconsultos, relativa ás cautelas e formalidades dos actos e contractos, á acção competente, aos actos processuaes,--maior influencia sempre teve como forma de manifestação da praxe; e essa opinião commum sempre foi recebida no fôro, segundo a phrase de F'EsTus: Receptum enim dicitur quicquid a plerisque prudentibus approvatum est. Tudo, porém, consiste em medir os limites dessa auctoridade da opiniâo commum e o abuso que della se pode fazer: sirva de lição o historico feito no discurso de Rocha Peniz, que serve de prefacio aos Elementos da Pratica Formularia, sobre a influencia da Escola dos glosadores, a ponto tal que a Lei de i 8 de Agosto de 1769 teve de declarar expressamente proscriptas no fôro as glosas de Accursio e Bartolo e as opiniơes dos Doutores que os seguiram, isto é, as opiniões de quasi todos os Praxistas dessa epocha. Por maior, porém, que tivesse sido a influencia dos juristas, nunca chegou ao abuso a que modernamente attingiu nos nossos tribunaes: temos visto sentenças e accordams, não só citando autores e tratados, como até transcrevendo trechos, e ainda mais, em lingua estrangeira. Lembrem-se os juizes que as partes querem ser julgadas por elles proprios, segundo o estudo delles e segundo a opinião delles; os juizes não podem dispensar-se 
de formar opiniâo propria, supprindo pela citação de tratados a sua indolencia para a exposição de argumentos directos. $\mathrm{Si}$ as partes quizessem regular seus direitos pela opinião dos tratadistas, não recorreriam aos tribunaes, iriam ás bibliothecas. Juiz, que cita tratadistas, mostra que leu, mas não mostra que tenha formado opinião propria. As partes querem ser julgadas pelos juizes, por argumentos directos e não pelo indirecto argumento das referencias a juristas e jurisconsultos, por mais famosos e auctorisados que estes sejam. Emfim, os juizes são obrigados a ter opinião propria, mesmo quando esta opinião concorde com a opinião commum; portanto, suas sentenças não devem citar os tratados, os commentarios, e muito menos os pareceres, nem mesmo para fazer remissões.

4. Nos capitulos segundo e terceiro da Introducção ao estudo da Pratica Forense, insertos na Revista da Faculdade de Direito de S. Pauln, I, pags, 12 I e 130, tivemos occasião de dar noções mais amplas sobre os formularios forenses, isto é, sobre o complexo das formulas forenses, para serem applicadas mutatis mutandis a cada relação particular de direito ou a cada acto processual. Para lá, portanto, remettemos os leitores que quizerem mais desenvolvidas idéas sobre o assumpto. Aqui faremos maior esforço em indicar como a confecção dos formularios póde intervir na formação da praxe forense. Não nos podemos furtar á tentação de traduzir os seguintes trechos de JHERING, Espirito de Direito Romano, III, 270: «O formulario nos dá uma imagem fiel do acto em toda a sua extensão e conteúdo. Razões poderosas de commodidade e de opportunidade impõem o uso dos formularios: assim, encontramol-os, mais ou menos perfeitos, em todas as epochas e em todas as legislações. Dispensando os contractantes de confeccionarem elles proprios 
os seus contractos, o formulario offerece-lhes uma redacção feita de ante-mão, estabelecida, em geral, por mãos peritas, uma redacção que já deu suas provas na vida; o formulario, além disso, assegura-lhes a vantagem de attrahir a attenção das partes para todos os pontos que importam observar. De facto, o formulario representa $\mathrm{o}$ papel de conselheiro prudente $\mathrm{e}$ fiel».

5. Ha formularios officiaes e formularios officiosos: os primeiros são autorizados ou approvados pelo Governo; os segundos são confeccionados por jurisconsultos e por praticos sem mandato publico. Em geral, o Governo não autoriza ou approva formulario sinão para casos em que a observancia das formas é de rigor de direito, ou para os casos em que se tratem de actos sujeitos não só á fizcalização das autoridades judiciarias, como á inspecção das autoridades administrativas. Assim, entre os formularios officiaes da primeira categoria, temos o formulario do processo criminal, confeccionado por Pimenta Bueno, recommendado pelo Aviso-circular de 27 de Março de 1854 , revisto depois do Dec. n. 4824 de 22 de Novembro de I 87 I, pelo conselheiro Silva Mafra; nas mesmas condições temos o formulario para diversos processos estabelecidos na legislação militar, approvado pelo Dec. n. I680 de 24 de Novembro de I855, etc. Entre os formularios officiaes da segunda categoria, temos os annexos aos Regulamentos consulares, para escripturas publicas, instrumentos de approvação de testamento, protesto e legalisação de documentos, reconhecimentos de firmas, etc., dos quaes o ultimo é o approvado pelo Dec. n. 4968 de 24 de Maio de I872; temos o formulario das transcripções e inscripções no Registro hypothecario, approvado pelo Dec. n. 544 de 5 de Julho de I 890; temos o formulario dos assentos do Registro 
Civil, annexo ao Dec. n. 9886 de 7 de Março de 1888 , e outros. Quanto aos formularios officiosos, temos as obras de Correa Telles, quer no Manual de Tabellião, quer no formulario de libellos, os de Menezes, CoRdetro, Coroatá, Nabuco, Machado, Ferrão, Miranda, Botelho, Teixerra de Freitas e muitos outros.

6. Na Inglaterra, a confecção e explicação dos documentos sellados ou formaes, os quaes se devem distinguir dos simples manuscriptos, cujo estudo faria objecto da Diplomatica, já constituem uma sciencia particular com sua litteratura propria. Em França, os formularios de DALLOZ e VERG ́, são considerados como obras de grande monta. Não ha razão, pois, para que se mantenha o desprezo que alguns espiritos, tanto mais mediocres quanto arrogantes, manifestam por esses continuadores das locubrações que tanta fama deram a Marculfo, Irnerio, Accursio e Rolandino: os formularios «são um producto artistico do espirito juridico». Seria mais util que, em vez. de ostentarem esse desprezo, se applicassem á analyse das FORMulas, estudo esse tanto mais necessario quanto, em muitos casos, como, por exemplo, nos instrumentos de approvação de testamento, ha formalidades de rigor, que não devem nem podem antepor-se, pospor-se ou substituir-se por equipollencia (Assento de I 7 de Agosto de I8I I).

7. Não temos a pretenção de voltar aos tempos da tenaz e supersticiosa adhesão dos Romanos ás palavras das formulas: mas, a verdade $e$ que os formularios são, em geral, um resultado de cautelas despertadas por muitas experiencias e, portanto, um poderoso elemento para a formação da praxe. «Muitas disposições de direito, diz o citado JHERINf, foram iniciadas por disposição das partes: esta transformação de disposições convencionaes em disposições legaes é um dos phenomenos mais notaveis na historia da formação do direito; 
e muitas regras de direito não podem ser comprehendidas sem o conhecimento de sua forma pre-legal, isto é, convencional». Aliảs, si o direito, como é sabido, vive e desenvolve-se na seio do povo, e si a historia $e$, na phrase de Cujacio, «esse anzol de ouro para pescar nas profundezas do direito civil e trazer das trevas á luz thezouros preciosos», é força reconhecer que esse elemento da interpretação encontra boa fonte nos formularios: os protocolos e mais livros dos cartorios dos notarios ou tabelliães e dos officiaes de registro contêm a historia da propriedade, a historia das obrigaçoes, a historia das familias; o protocolo e autos dos cartorios dos escrivães contêm a historia das duvidas que occorrem na applicação da lei, a historia das acções, a historia das successões, a historia da criminalidade. $\mathrm{E}$ todo esse desenvolvimento historico melhor se manifestará quanto mais perfeitas forem as formas, quanto mais aperfeiçoadas forem as formulas, quanto mais definidas forem as formalidades e quanto mais determinados forem os respectivos effeitos. 